\title{
The Impact of Human Resources Management on Employee Performance: Organizational Commitment Mediator Variable
}

\author{
Esmael M. A. Tabouli ${ }^{1}$, Nasser Ahmed Habtoor ${ }^{1} \&$ Mohammad Nashief S. ${ }^{1}$ \\ ${ }^{1}$ Faculty of leadership and Management, Universiti Sains Islam Malaysia, Malaysia \\ Correspondence: Esmael M. A. Tabouli, Faculty of leadership and Management, Universiti Sains Islam Malaysia, \\ Malaysia. E-mail: e.etbouly@yahoo.com
}

Received: June 26, 2016

doi:10.5539/ass.v12n9p176
Accepted: July 19, $2016 \quad$ Online Published: August 26, 2016

URL: http://dx.doi.org/10.5539/ass.v12n9p176

\begin{abstract}
This study aims to examine the impact of the human resource management (HRM) policies on the organizational commitment and the performance of the employees at Jumhoruia bank in Libya. The study encompasses the policies factor as an independent variable and the factor of employee performance as a dependent variable. This study also intends to investigate the role of "organizational commitment" as a mediator variable between the polices of (HRM) and the performance of the employee, and to achieve these aims, the researchers have used the descriptive analytical method (quantitative) which represented using (CFA) in order to verify the structural truth of the study factors reaching to use (SEM-AMOS). The study is targeting all employees working in Jumhoruia bank, the headquarters and the branches in the capital city of Libya, Tripoli The study has concluded with many results, and one of the most important results is that, there is a positive relationship between the (HRM) and the employees' performance. The study also found that there is an indirect positive effect to the (HRM) through the organizational commitment with a percentage higher than the direct impact. the researchers recommends that all policy makers of (HRM) should pay more concern on policies and practices related to the employees which results into developing the employees' performance, also policy makers inside the bank should concentrate on emotional aspects of the employees which in turn result into a higher positive influence on their performance compared with the direct impact on their performances.
\end{abstract}

Keywords: human resource management, employee performance, organizational commitment

\section{Introduction}

Annual reports and cooperation statements underlies one common message indicating that humans represent most valuable resources. Thus, the key element to the success and survival of a given organization is the availability of the right personnel at the right place and at the right time (Oladipo, 2011). As proclaimed by many firms, humans represent a source of a competitive advantage regardless of whether those people are visionary managers, accommodating customer service experts or even technological experts. Hence, at a time when the technological development is unparallel it is only the human resource that can play an important role in the success or failure for all firms, specifically entrepreneurial firms (Katz et al., 2000). It is apparent that there is an awareness of the speedy and complicated changes occurring in the market environment among organizations and managers. This remarkably results into changing attitudes of some firms towards human recourses. People or humans in organizations as perceived by top managers are regarded as the most valuable strategic resources (Pfeffer, 1994). Therefore, those organizations which have long-term objectives usually make effort into re-examining how to manage their human resource. This is known as human resource management (HRM) which is a term indicating how such organizations give much importance to the role of managing their human recourse

Within the emergence of HRM, recently, researchers have paid much attention to this, specifically the effect of human resource practices on performance of organizations and employees' attitudes as an interesting research area especially in the context of developed countries. Yet, little is known about the impact of HRM in the context of developing countries (Sarbariy, 2011). This suggests the need for further research on HRM in such developing countries such as Asia or Africa. This is because this research will assist in meeting the shortage of empirical work in organizations in such countries. It is also expected that investigation of this research area will function as a vehicle for comparative studies. Previous studies investigating the effect of HRM on organizational 
performance, have focused on this in different industries at the same time (Davision et al., 1996; Wyatt's, 2002). However, there are others researchers (e.g., Inchniowski et al., 1995) pointing out that investigation of HRM can be advantageous when it focuses on this in a single industry. They also suggested that investigation of HRM in a single industry resulted into precise measurement of organizational performance, HRM practices, and control variables. Therefore, the current study focuses its investigation of HRM in the banking sector in Libya.

\section{Issue}

Although HRM plays an important role in enhancing the performance of employees and organizations, many organizations in developing countries such as Libya do not pay much attention to HRM in order to ensure such effective performance of their employees. There are, in fact, a few related studies on HRM in Africa in general and Libya particular in comparison to the wide number of studies in Europe, America, and different parts of Asian continents. Moreover, these few studies in the Libyan context focused their investigation on HRM and employees' performance while ignoring the importance of organizational commitment Yasir et al. (2011), Gaafar (2012), Abdul Hameed et al. (2014), Fahad et al. (2014), Uzma (2015). Therefore, the aim of the present study is to examine the effect of HRM on employees' performance through organizational commitment as a mediator variable in order to bridge the above mentioned gap in previous research.

\section{The Objective of the Study}

The main objective of the current study is to investigate the impact of HRM practices on the employee performance and organizational commitment in Jumhouria Bank in Libya as the study setting. To achieve this objective, the following specific objectives are stated:

1. To investigate the relationship between HRM and employees' performance in Jumhouria Bank.

2. To investigate the relationship between HRM and employees' performance through the mediator variable of organizational commitment in Jumhouria Bank.

\section{Scope of Study}

The investigation carried out in the present study is scoped to evaluation of the impact of HRM on employees' performance directly and indirectly via organizational commitment as a moderator variable in the setting of Jumhouria Bank in Libya

\section{Literature Review}

\subsection{Human Resource Management}

In its initial development, the US management concept of HRM denotes the attention and importance given to individual workers or employees and the need for treating them as assets rather than cost (Wilkinson, 1990). Although the concept received a wide acceptance as new management practices, it has remained undefined because of its different applications. As identified by Guest (1987, p. 504) there are three major approaches to HRM. First, HRM is considered as a new title for personnel management, indicating that organizations should rename their personnel department without having to make any changes to their practices. Secondly, HRM is regarded as conceptualization and recognition of personnel roles and description of the work of personnel department. Thirdly, HRM is viewed as a totally new approach to managing originations in a distinctive way and integrating human resource into strategic management. Thus, this third approach to HRM emphasizes the importance of fully and positively utilizing on full and human resources. In brief, HRM refers to a set of policies which are developed with the aim of maximizing organizational integration, employees' commitment, flexibility and quality.

\subsection{Employee Performance}

Performance of employees related to their jobs has been a major concern for both organizations and researchers. For decades, organizations and researchers have been seeking diverse means to enhance or improve employees' performance. Thus, in its simple definition, job performance is the employees' behaviors or actions associated to the aims or goals of the organization in question" (McCloy, Campbell, \& Cudeck, 1994). Performance is defined as a variable having multiple dimensions and distinct components and elements according to the job (McCloy et al., 1994). Porter and Lawler (1968) argued that attitudes influence performance. For instance, previous researchers, Christen, et al. (2006), Cohrs, et al. (2006), Rayton (2006), and Zhang (1999) provided evidence indicating that employees' job satisfaction as an attitudinal variable affects or influences their job performance which is a behavioral variable. Based on the results of their empirical study, Lawler and Porter (1967) stated that employees' satisfaction of their higher order needs is most closely associated with their job performance. From these previous studies investigating the effect of employees' satisfaction on their job performance, the issue that 
has not been resolved yet is the causal direction between job satisfaction and job performance.

\subsection{Organizational Commitment}

Porter (1990) views or defines organizational commitment as the constant tendency of employees to engage or take part in specific activities related to their organization. It is a result of employees' investment in this organization and their fears of losing their jobs if they are not committed to their work. As added by Rebecca (2013), organizational commitment is seen as a means that does not only connect employees to the aims or goals of their organization, but also creates among them a sense of values and acceptance of these identified goals and makes them willing to put into much effort on behalf of the organization to survive and continue its membership. Qaisar et al. (2012) also defined organizational commitment from a psychological perspective. In this regard, it is defined as a psychological means of connecting individuals to their organization, motivating them to work harder and pushing them to adopt the values of the organization, thus positively affecting the productivity and effectiveness of their organization.

Some earlier researchers reported results confirming that organizational commitment has significant contributions to achieving the goals of organizations and accomplishing the work within a short time, least effort and least cost. This is because it motivates employees to work harder or engage deeply in their work. Moreover, their results of showed that the longer time employees work in a given organization, the more experience and higher competence they will achieve. Thus, in turns, fosters their productivity as well as the productivity of their organization (Salleh et al., 2013; Yeh et al., 2012).

\section{Theoretical Background and Hypotheses}

Organizational capacities are viewed as the results generated from the processes of re-defining and re-distributing the practices, professionals and functions of HRM. Previous researchers (Guest, 1987; Storey, 1995; Legge, 2006; Bohlander \& Snell, 2009) pointed out at the possibility of observing the strategic and relevant role of people in organizations. Therefore, the researchers emphasize the need for cohesive and coherent theories which are aligned to both planning and organizational strategy to properly sustain HRM. This indicates that policies and practices of HRM are likely to vary among organizations, but they need to be aligned with business strategy (Chênevert \& Tremblay, 2009). According to Boxall and Purcell (2000), the impact of the person's HRM practices relies upon both the nature of the impact of other HRM practices as well as the business strategy. It was also argued by Lim (2012) that the external business environment strongly influences the activities and practices of HRM.

Approaching this from the strategic HRM perspective, there is a mutual reinforcement between both policies and practices, and both strongly affect the organizational goals (Morris \& Snell, 2010). Furthermore, the logic of skills being developed according to the requirements of business processes serve as guidance for policies of HRM (Serpell \& Ferrada, 2007). In other words, they provide tools for capturing and communicating the strategic vision and objectives of the organization in clear, easily understood terms (Vakola, Soderquist, \& Pratascos, 2007). In this context, the aim of proposing and developing scales that permit an estimation of how HRM policies are perceived is identification of the degree of the applicability of such developed scales to a variety of organizations and their alignment with the strategy of a given organization. A developed scale can be effective or efficient when it is capable of translating the association between HRM policies and the business strategy (Legge, 2006).

It is a must for HRM not to be relegated to a traditional supporting role anymore. However, it is a must that HRM constitutes up an essential competence so that it can reach or achieve the aims at the organizational and individual levels. This is important especially because of the value of human resources as a source of competitive advantage. For instance, based on the review of research by Uysal (2012), the major HRM policies such as staffing, training, performance evaluation and compensation are strongly and positively as well as significantly correlated. Such results are of importance for obtaining a better understanding of the inter-relationships between HRM practices so that the effect of the HR systems on employee-based organizational outcomes can be enhanced (Demo, Neiva, Nunes, \& Rozzett, 2012).

In such context, organizations have shifted to the perspective of competitive advantage creation. As a result, there themes which are relevant to the areas of organizational strategy and theory that converge, thus underlying comprehensive implications for HRM and putting its primary function under discussion. As pointed out by the Resourced Based View by Barney (1991), creating such competitive advantages normally relies upon on prerequisites that may be closely relevant to the HRM area because these resources should be valuable and rare to the organization. They may never be imitated or substituted, and the ability of the organization to exploit them is a must. Beauvallet and Houy (2010) emphasized the need for supporting the key mechanism and decisive 
variable which would be able to provide justifications of the direct relation between the competitive advantages of companies which are alleged as lean enterprises, or the ones that usually practice a lean management and HRM.

Concerning the definition of the term of organizational policy, it refers to the principles which are set up or developed for leading a company. It is also known as a general course of action of developing joint or collective practices in a constructive way that aim at reaching or achieving particular objectives (Singar \& Ramsden, 1972). Thus, HRM policies aim at defining the attitude, expectations and values of the organization related to treating in the individuals, and therefore, they still function as point of reference for developing the organizational practices and for making decisions people in addition to resulting in equal treatment among individuals (Armstrong, 2009). For the present study, we use this term of HRM policy to refer to any proposals which are organizationally articulated within the theoretical and practical constructions of human relations and which are intended to achieve the wanted outcomes. Thus, HRM policies define the theoretical as well as the practical referential established for making achievement of the objectives and purposes of that organization possible. In other words, they function as thoughts that guide the HRM area.

Results of some previous studies have showed that HRM policies are positively related to variables such as commitment, productivity, profitability and quality (Guest, 1987; Schneider \& Bowen, 1985; Ulrich, Halbrook, Meder, Stuchlik, \& Thorpe, 1991). In addition, the results obtained by Combs, Liu, Hall, and Ketchen (2006) from a meta-analysis confirmed positive relationships between practices of human resources and organizational outcomes, and such relationships were also found to be stronger in manufacturing companies than they were in service companies. In the same vein, other previous studies reported policies and practices of HRM had favorable effect on the performance of organizations (Boselie, Dietz, \& Boon, 2005; Menezes, Wood, \& Geladi, 2010; Subramony, 2009). The results reported by Guest and Conway (2011) also support the evidence that more HRM practices are conducive or lead to higher effectiveness of HR and a higher range of performance outcomes.

In a study by ALDamoe, Yazam and Ahmid (2012), it was concluded that the retention of employee probably plays a role in mediating the relationship between HRM practices and organizational performance. Moreover, how employees perceive HRM policies and practices has its influence on discretionary work effort as well as co-worker assistance (Frenkel, Restubog, \& Bednall, 2012). However, the efficiency and acceptance of HRM policies are relevant to the organizational values and culture (Stone, Stone-Romero, \& Lukaszewski, 2007). To sup up, HRM policies play an important role in developing, appreciating and retaining talents. They also foster employees' commitment or accountability, which motivates them to act and work or perform their work in a more flexible and adaptive way and pushes them to move towards excellence in organizations (Legge, 2006). Therefore, planning an entrepreneurial strategy should take into account that such strategy that aims at producing and supplying the added-value products and services should address developing and implementing HRM policies that will result in better qualifications of employees in a given organization (Legge, 2006).

Recently, within the increasing dynamic nature of HRM, there has been an increasing need calling for more studies on the effect of HRM practices on employees' organizational commitment. For example, as believed by Meyer and Allen (1997), it is important for studies to fully examine the relationship between HRM practices and employees' commitment. The same researchers emphasized the need for further studies on identifying the antecedents related to the multiple domains of employees' commitment. Management should also retain its best workers and make them committed to its organization so that it can attract other quality employees. Therefore, researchers interested in studying organizations, employment and other related domains or areas should give more attention to employees' commitment as their primary focus of research (Scarpello, Ledvinka, \& Bergman, 1995).

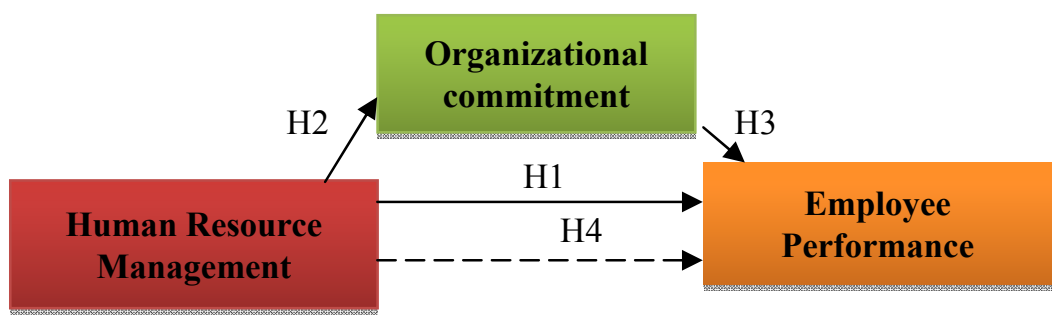

Figure 1. Research Framework

Many previous studies have investigated organizational commitment, thus proving that such commitment is a 
result of HRM (DeCotiis \& Summers, 1987; Mathieu \& Zajac, 1990). As reported by Delaney and Huselid (1996), organizational commitment is affected by several factors, including empowerment, recognition, fair rewards, sharing information and development of employees' competence. In spite of investigation of organizational commitment in previous studies, the factors that affect promotion and development of such commitment are still ambiguous or not well identified yet (Beck \& Wilson, 2001).

\subsection{Hypotheses}

In order to achieve the objectives designed for this study, the following research hypotheses are stated based on the revelation in the review of literature concerning (HRMPP) and employee performance.

Hypotheses 1:

There is significant positive correlation between human resource management and employee performance in Jumhouria bank.

Hypotheses 2:

There is significant positive correlation between human resource management and organizational commitment in Jumhouria bank.

Hypotheses 3

There is significant positive correlation between organizational commitment and employee performance in Jumhouria bank.

\section{Hypotheses 4:}

There is significant positive correlation between human resource management and employee performance through organizational commitment in Jumhouria bank.

\section{Research Methodology}

\subsection{Data Collection}

For this study, the data was collected from primary and secondary sources. The primary source is represented by the survey, while the secondary source includes extensive desk research through library, different published material and world-wide web. Concerning the survey, a questionnaire was developed with the aim of measuring HRM practices, employees' performance and organizational commitment. It is believed that survey is an easier approach to data collection (Yu \& Egri, 2005). For the HRM practices in the questionnaire, the questionnaire items covered five dimensions: recruitment and selection policy, involvement policy, performance appraisal policy, compensation and rewards policy \& training and development policy. All these items of the HRM practices were derived from the review of previous literature on HRM, specifically adopted from previous researchers (Huselid, 1995; Guest, 1998; Pfeffer, 2005; Rubino, Demo \& Traldi, 2011). The dependent variable, the employees' performance, is a construct that is measured through four dimensions: efficiency of the work, planning the work, creativity and innovation, making efforts. The items for this construct or variable were taken from Nassazi, (2012) and THI, (2012). The mediator variable, the organizational commitment, is a construct comprising three dimensions: affective commitment, continuous commitment and normative commitment. The items for this construct were adopted from Al Qasim, (2011) and Abazid, (2014). The questionnaire in its three sections consists of an overall number (50) of items or questions which needed to be responded to by the respondents using a five- points Likert scale: $1=$ strongly disagree to $5=$ strongly agree. Thus, prior to administering the questionnaire to the participants, the questionnaire was translated into Arabic since the respondents do not use English, and a note explaining the intention of the researcher to collect the data was attached to it. Then, the researcher distributed a total number of (455) questionnaires to the respondents, while the returned questionnaires were (407), thus representing almost $84 \%$. Moreover, some of these returned questionnaires missed important information, and therefore, they were excluded. As a result, a total of (381) questionnaire were determined as usable and entered into statistical analysis. Distribution and collection of the questionnaires were distributed and collected for a period of time from October (2015) to March (2016).

\subsubsection{Sampling}

In this study, employees working in Jumhouria Bank in Tripoli in Libya represent the target population. However, 455 employees were randomly chosen as the sample respondents in this study. This was performed using a random sampling technique. 


\section{The Most Important Statistical Methods Used in This Study}

\subsection{Confirmatory Factor Analysis}

In order to test the validity constructs and the research hypotheses the Structural Equation Modeling (AMOS) model-fitting program is used. The model fit is evaluated by using four indices of the model goodness-of-fit: (1) the comparative fit index (CFI) (2) the chi-square statistics McDonald and Marsh (1990); (3) (RMSEA) between $(0.08)$ to $(0.10)$ indicates a mediocre fit Browne and Cudeck (1993) and would not employ a model a RMSEA greater than $0.1(>0.1)$ (MacCallu um et al., 1996). (4) The minimum value of the discrepancy between the observed data and the hypothesised model divided by degrees of freedom (CMIN/DF) or normed chi-square. Marsh and Hocevar (1985).

\subsection{Construct Validity}

According to Hair, Black, Babin, Anderson and Tatham (2006) the employment of factor loading composite reliability (CR) and average variance extracted (AVE) to determine the convergent validity if it equals to or greater than $0.5(\geq 0.5)$ and the composite reliability equals to or greater than $0.7(\geq 0.7)$ if were recommended by Hair et al. (2006). Also, (AVE) reading values should be greater.

\section{Data Analysis and Result Discussions}

\subsection{Confirmatory Factor Analysis for Variables and Measurement Scales}

\subsection{1 (CFA) Human Resources Management}

The outcome of the goodness-of-fit of the end revision of the Human Resources Management model displayed that normed chi- square (CMIN/DF) was (3.179) which did not exceed (5), the (CFI) was (.947) which was higher than (90), and the RMSEA index was (.076) which was less than (.080). Figure (3) shows the adequacy of the final revised of the Human Resources Management model.

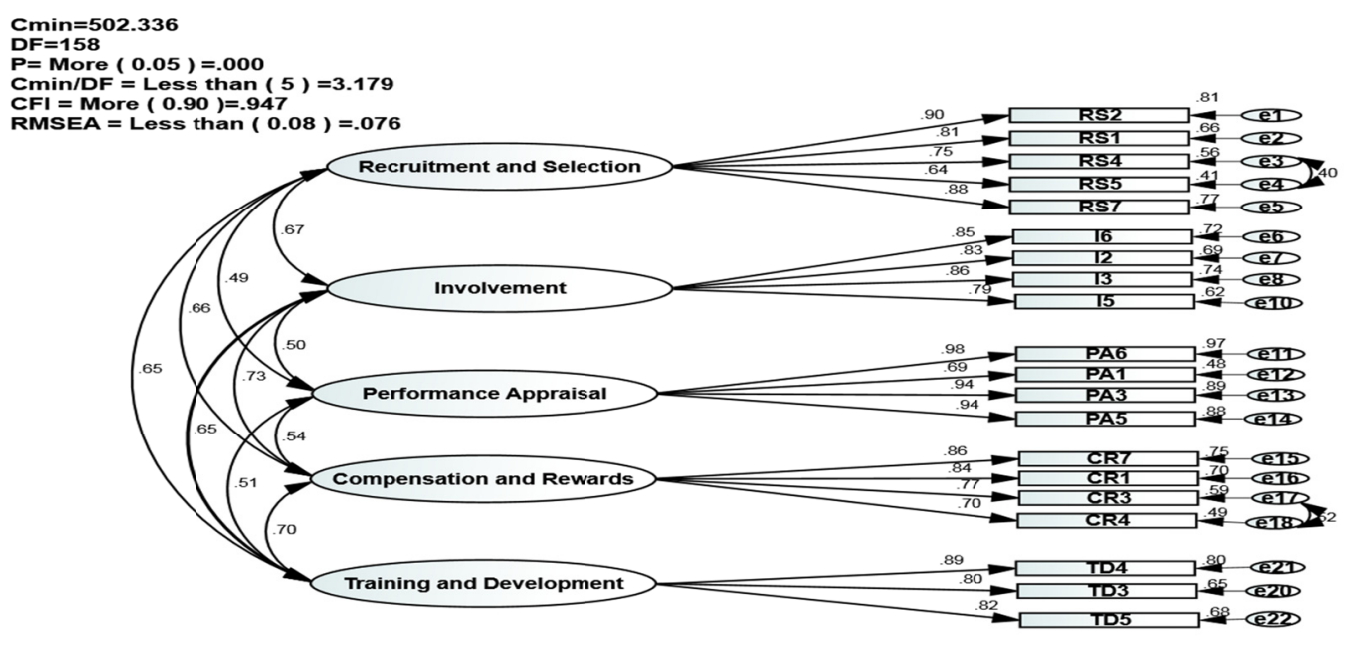

Figure 2. Human Resources Management model after amendment

Table 1. Covariance and the contrast between the extracted five-factor matrix (HRMPPS) model

\begin{tabular}{lllllll}
\hline No & factor & Recruitment & Involvement & Performance & Compensation & Training \\
\hline 1 & Recruitment & 0.64 & - & - & - & - \\
2 & Involvement & 0.45 & 0.54 & - & - & - \\
3 & Performance & 0.24 & 0.25 & 0.81 & - & - \\
4 & Compensation & 0.44 & 0.53 & 0.29 & 0.63 & - \\
5 & Training & 0.42 & 0.42 & 0.26 & 0.49 & 0.71 \\
\hline
\end{tabular}

\subsubsection{Construct Validity}

In this research, the parameters ranged from (0.64 to 0.98$)$ for the factor lodging; all constants being above (0.5) 
$(\geq 0.5)$. Furthermore, the AVE readings were $(0.64,0.54,0.81,0.63,0.71)$ where the value was greater than $(0.5)$ $(\geq 0.5)$ and which were even higher than shared variance (SV) as depicted in Table 2 . Hence, the criteria of the (AVE) discriminant validity of the model are met. Universally, the measurement model of the Human Resources Management model was fit and met the criteria as shown in Table 1 and Figure 2.

\subsection{2 (CFA) Employee Performance}

The outcome of the goodness-of-fit of the end revision of the Employee performance model displayed that normed chi- square (CMIN/DF) was (2.217) which did not exceed (5), the (CFI) was (0.964) which was higher than (90), and the RMSEA index was (0.057) which was less than (.080). Figure 3 shows the adequacy of the final revised of the Employee performance model.

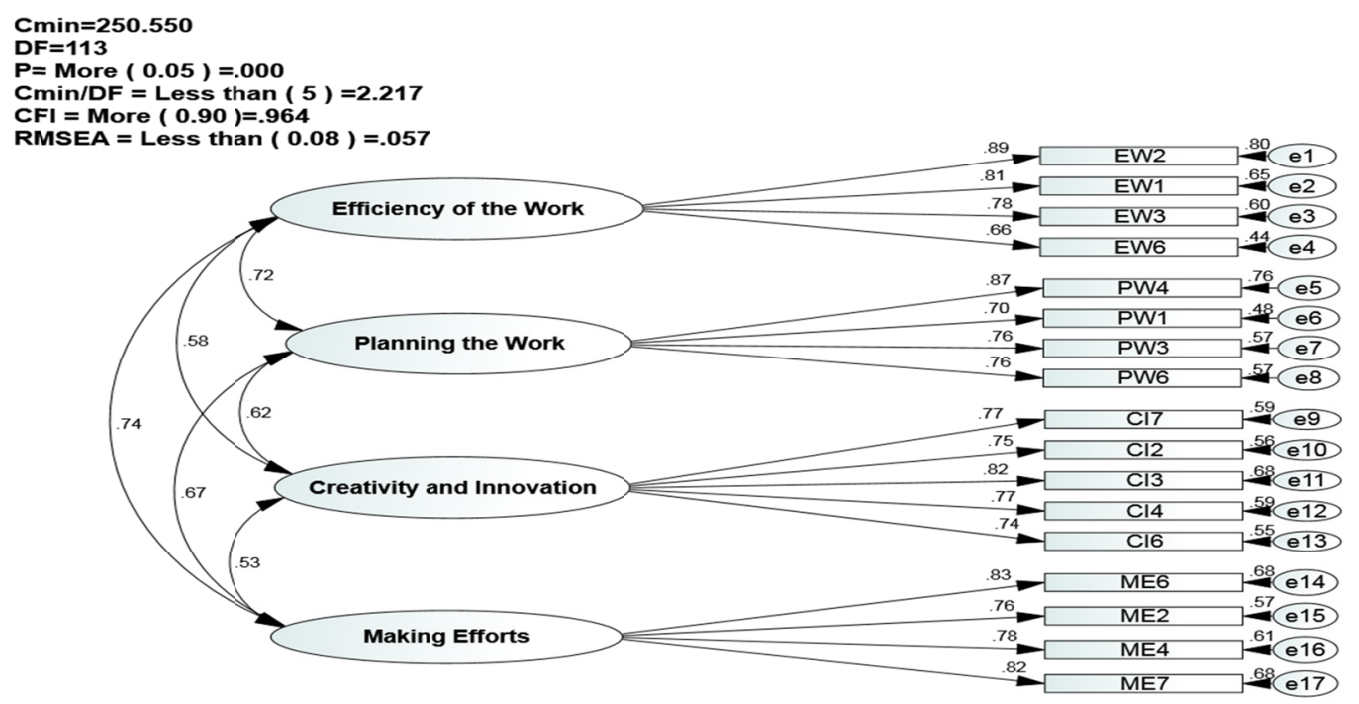

Figure 3. Employee performance model after amendment

Table 2. Covariance and the contrast between the extracted four-factor matrix Employee performance model

\begin{tabular}{llllll}
\hline No & factor & Efficiency & Planning & creativity & Making Efforts \\
\hline 1 & Efficiency & $\mathbf{0 . 6 2}$ & & & \\
2 & Planning & 0.52 & $\mathbf{0 . 6 0}$ & & $\mathbf{0 . 5 9}$ \\
3 & creativity & 0.34 & 0.38 & 0.28 & $\mathbf{0 . 6 4}$ \\
4 & Making Efforts & 0.55 & 0.45 & \\
\hline
\end{tabular}

\subsubsection{Construct Validity}

In this research, the parameters ranged from $(0.66$ to 0.89$)$ for the factor lodging; all constants being above $(0.5)$ $(\geq 0.5)$. Furthermore, the AVE readings were $(0.62,0.60,0.59,0.64)$ where the value was greater than $(0.5)(\geq 0.5)$ and which were even higher than shared variance (SV) as depicted in Table 2. Hence, the criteria of the (AVE) discriminant validity of the model are met. Universally, the measurement model of the Employee performance model was fit and met the criteria as shown in Table 2 and Figure 3.

\subsection{3 (CFA) Organizational Commitment}

The outcome of the goodness-of-fit of the end revision of the Organizational commitment model displayed that normed chi- square (CMIN/DF) was (3.311) which did not exceed (5), the (CFI) was (0.953) which was higher than (90), and the RMSEA index was (0.078) which was less than (.080). Figure 3 shows the adequacy of the final revised of the Organizational commitment model. 


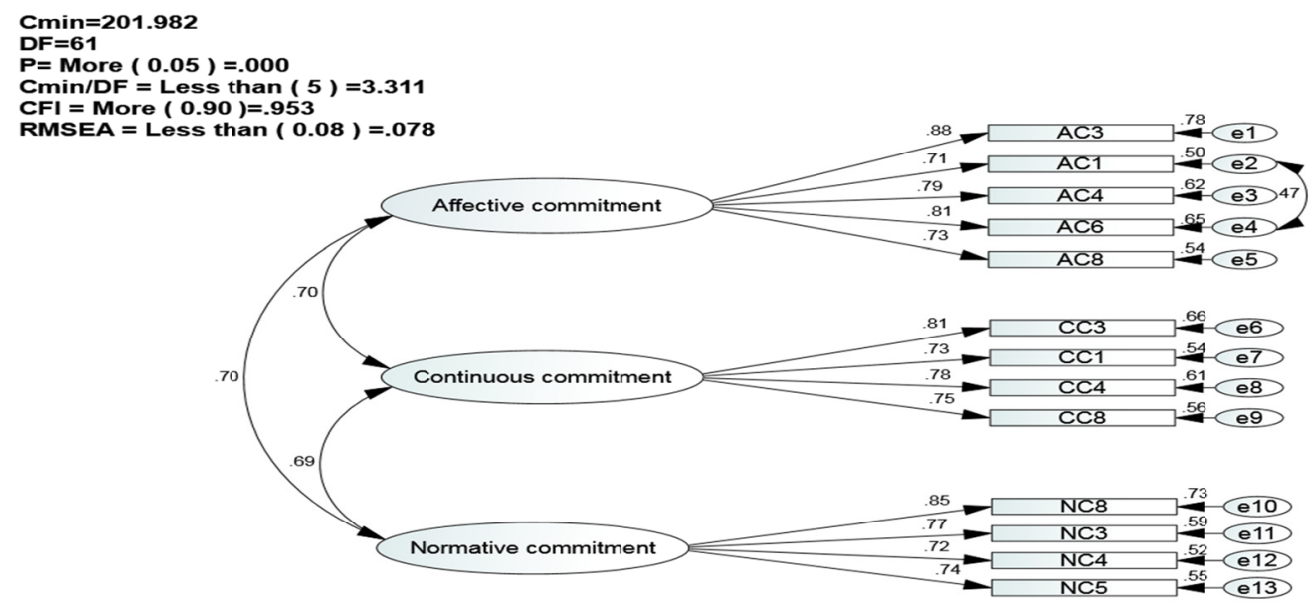

Figure 4. Organizational commitment model after amendment.

Table 3. Covariance and the contrast between the extracted three-dimensional matrix organizational commitment scale

\begin{tabular}{ccccc}
\hline No & Latent Variables & Affective Commitment & Continuous Commitment & Normative Commitment \\
\hline 1 & Affective Commitment & $\mathbf{0 . 6 2}$ & - & - \\
2 & Continuous Commitment & 0.49 & $\mathbf{0 . 5 9}$ & - \\
3 & Normative Commitment & 0.49 & 0.47 & $\mathbf{0 . 6 0}$ \\
\hline
\end{tabular}

\subsubsection{Construct Validity}

In the present study, the lodging for the parameters factor ranged from ( 0.71 to 0.88$)$; with all parameters were above $0.5(\geq 0.5)$.Furthermore, the AVE readings were $(0.62,0.59,0.60)$ where the value was greater than $(0.5)$ $(\geq 0.5)$ and which were even higher than shared variance (SV) as depicted in Table 2. Hence, the criteria of the (AVE) discriminant validity of the model are met. Universally, the measurement model of the Organizational commitment model was fit and met the criteria as shown in Table 3 and Figure 4.

10. Examination of the Theoretical Model by Use of the Integrated Formula of Structural Equation Modeling

10.1 Examination of the Standard Theoretical Research Model Using a CFA

\subsubsection{Main Standard Model}

Table 4. Values of the fit indices of the model

\begin{tabular}{cccc}
\hline Indicators Consistency & $\begin{array}{c}\text { Measurement Model } \\
\text { Figure } 5\end{array}$ & $\begin{array}{c}\text { Structural Model } \\
\text { Figure } 6\end{array}$ & $\begin{array}{c}\text { Function value on the } \\
\text { quality of conformity }\end{array}$ \\
\hline index value & index value & \\
Cmin & 78.894 & 78.894 & -- \\
df & 51 & 51 & --- \\
P & .0070 & .0070 & None \\
Cmin/Df & 1.547 & 1.547 & Less than $(5)$ \\
CFI & .9900 & .9900 & More $(.90)$ \\
RMSEA & .0380 & .0380 & Less than $(.08)$ \\
\hline
\end{tabular}

After determining the statistical expectations compulsory to the analysis using Structural Equation Modeling, the 
sample shall be verified in terms of the identical to the sample data, and then the hypotheses shall be verified in the default theoretical model. Through the Figure 5 which shows the scheme of default theoretical model of the study using the method of Structural Equation Modeling by (AMOS).It is shown that there is an identical between the theoretical model with the data or factual event in the study environment. Furthermore, the scheme shows the identical indicators of model with the reality or the data collected from the study environment. Also clear that there is not a high correlation between the values of the underlying factors, this shows lack of a multicollinearity, which leads to Offending Estimation in structural equation modeling.

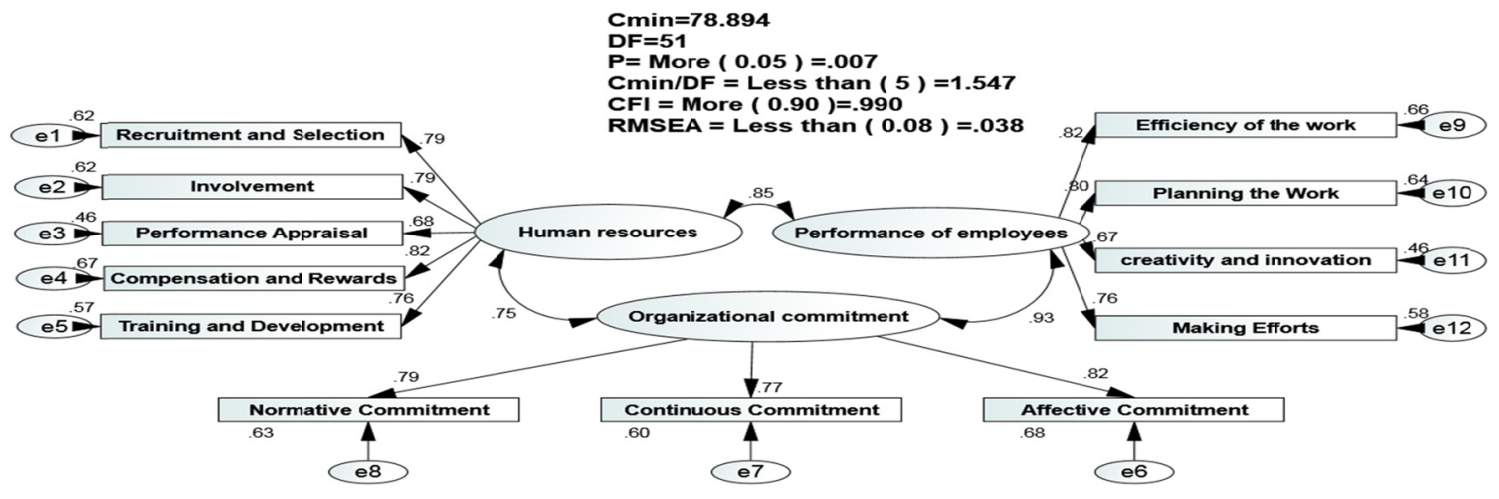

Figure 5. Modified Measurement Model

Using both the values and indicators of model consistency with the sample data (Model Fit Indices) as depicted in Table 4 and Figure 5, it is clear that there exists a goodness of fit between the measurement model and the data collected. The (Cmin) was (78.894), degrees of freedom (51), the significance level (.007) (which was statistically significant), in addition to the -Chi-square (1.547), which was less than (5), and (CFI) was (0.990), and which was higher than (0.90) all provide evidence confirming that the measurement model fits or has relations with the variables intended to measure in this study. The model is far from the null model (where there is a lack of such relations among the factors or variables). Furthermore, RMSEA index was (0.038), which is less than $(0.080)$, and this establishes the presence of the measurement model in the overall study population where the data was collected.

Based on this evidence showing the goodness of fit among the measurement model and the real study context through the collected data, it was possible to perform or carry out factor loading to check the internal or relationships hypothesized in the research model. Such loading means that relationships between the latent factors of the model and their underlying variables that represent them such as the relationship between the variable of Human Resources Management and its underlying variables (Recruitment and Selection, Involvement, Performance Appraisal, Compensation and Rewards, Training and development) were all above (0.60).

The same can apply to the other remaining latent factors and their underlying variables in this study. Here, the value of this relationship should be at least (0.50). As seen in Figure 5 and Table 5, the saturation or correlation estimates of the factors exemplified by (rectangle shapes) and the underlying variables represented by circles were great; besides that, they exceeded (0.50). These are normally termed factor loadings. In this research, Table 5 depicts the (CR) for every relationship between the factors and its underlying variables. The results show that the value was higher than (1.964) for each relation, which was also statistically significant or the significance level (0.05). Hence, considering the (CR) was greater than (1.964), this is indicative of the statistically significant level, thus confirming of the relationship between the factors of the model and the underlying variables. 
Table 5. Parameter and non-parameter estimates of the theoretical measurement model

\begin{tabular}{cccccccc}
\hline Latent variables & Observed variables & estimate & S. E. & C. R. & P & Loading & SMC \\
\hline & Recruitment and Selection & 1.000 & - & - & - & 0.79 & 0.62 \\
Human & Involvement & 0.815 & 0.050 & 16.372 & $* * *$ & 0.79 & 0.62 \\
Resources & Performance Appraisal & 0.734 & 0.054 & 13.686 & $* * *$ & 0.68 & 0.46 \\
Management & Compensation and Rewards & 0.875 & 0.051 & 17.091 & $* * *$ & 0.82 & 0.67 \\
& Training and development & 0.605 & 0.039 & 15.553 & $* * *$ & 0.76 & 0.57 \\
& Affective Commitment & 1.000 & - & - & - & 0.82 & 0.68 \\
Organizational & Continuous Commitment & 0.807 & 0.049 & 16.576 & $* * *$ & 0.77 & 0.60 \\
commitment & Normative Commitment & 0.831 & 0.049 & 17.090 & $* * *$ & 0.79 & 0.63 \\
& Efficiency of the work & 1.000 & - & - & - & 0.82 & 0.66 \\
Performance of & Planning the Work & 0.964 & 0.055 & 17.643 & $* * *$ & 0.80 & 0.64 \\
employees & Creativity and innovation & 0.986 & 0.070 & 14.135 & $* * *$ & 0.67 & 0.46 \\
& Making Efforts & 0.958 & 0.058 & 16.636 & $* * *$ & 0.76 & 0.58 \\
\hline
\end{tabular}

S.E. Standard Error, C.R.: Critical Ratio, P: Probability, SMC: Squared Multiple Correlations.

10.1.2. Examination of the Structural Model

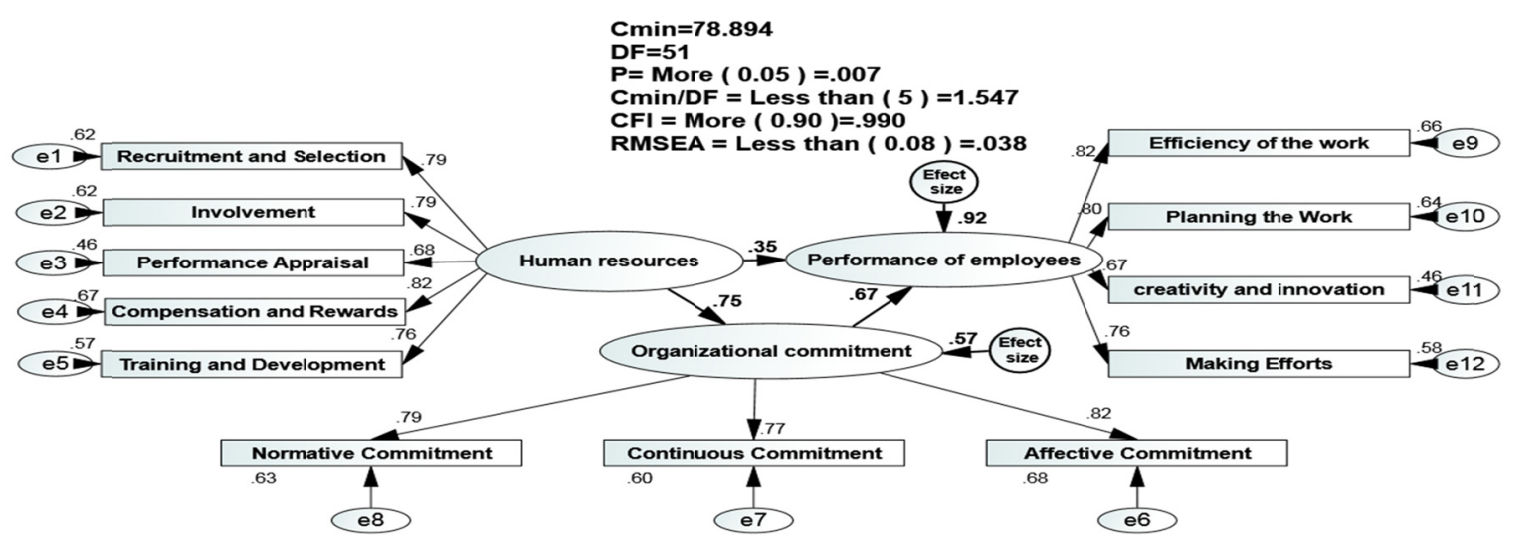

Figure 6. Structural Model

As shown in Figure 6, the structural model differs from the measurement model as depicted previously in Figure (5). The independent factor (Human Resources Management), the dependent factor (Performance of employees) and the mediating factor (Organizational commitment) were determined by the one headed-arrow $(\longrightarrow)$. However, in the measurement model, the relationships among these factors appeared to be independent relationships where the independent, dependent and mediating factors were not identified or determined. Moreover, the relationships among the three factors were represented by a two-headed arrow $(\leftrightarrow)$. The results or output of the use of Amos show that there is a consistency between the model and the data collected, which is also confirmed through the structural model, and there is a consistency between the measurement model and the structural model established using the previous values and indices as shown in Table 6 and Figures 5, and 6 where the collected data of the current study was consistent with the model.The (Cmin) was (78.894), degrees of freedom (51), the significance level (0.007) (which was statistically significant), in addition to the -Chi-square 
(1. 547), which was less than (5), and (CFI) was (0.990), and which was higher than (0.90) all provide evidence confirming that the measurement model fits or has relations with the variables intended to measure in this study. The model is far from the null model (where there is a lack of such relations among the factors or variables). Furthermore, RMSEA index was (0.038), which is less than (0.080), which establishes the presence of the measurement model in the overall study population where the data was collected. Based on these values and indexes indicating the consistency among the structural model and the real Libyan environment, the research hypotheses were examined.

\section{Examination of the Main Research Hypotheses of the Model}

After certifying the observed relationships between the underlying variables and the factors as formerly reviewed, the main hypotheses of the research model were tested as follows:

(H1): There is significant positive correlation between Human Resources Management and employee performance in Jumhouria bank.

The research hypothesis confirmed the positive and direct effect of Policies used for Human Resources Management on employee performance. Based on the research model illustrated in Figure 6, Table 6 showing the output of Amos, this research hypothesis was of statistically significant level since the (C. R) was (5.618), which was greater than (1.964), and the value of the significance level $(0.05)$ was lower than $(0.05)$. In addition, the path coefficient was (0.35), a decisive direction, which confirms that the Policies used in Human Resources Management to an increase in the development of employee performance.

Table 6. Results of the levels of correlations between the factors of the model

\begin{tabular}{|c|c|c|c|c|c|c|c|}
\hline Latent variable & S. R. W & Latent variable & $\mathbf{E}$ & S. E & C. $\mathbf{R}$ & P-Value & S. R. W \\
\hline $\begin{array}{c}\text { Human Resources } \\
\text { Management }\end{array}$ & $-\cdots->$ & $\begin{array}{l}\text { employee } \\
\text { performance }\end{array}$ & 0.277 & 0.049 & 5.618 & 0.000 & 0.35 \\
\hline $\begin{array}{c}\text { Human Resources } \\
\text { Management }\end{array}$ & $--->$ & $\begin{array}{c}\text { organizational } \\
\text { commitment }\end{array}$ & 0.708 & 0.055 & 12.784 & 0.000 & 0.75 \\
\hline organizational commitment & $--->$ & $\begin{array}{l}\text { employee } \\
\text { performance }\end{array}$ & 0.572 & 0.058 & 9.794 & 0.000 & 0.67 \\
\hline
\end{tabular}

R.S.W: Standardized Regression Weights, C.R: Critical Ratio, S.E: Standard Error, E: Estimate.

(H2): There is significant positive correlation between Human Resources Management and organizational commitment in Jumhouria bank.

The second research hypothesis also confirmed a presence of a decisive and direct effect of Human Resources Management on the organizational commitment. As depicted in Figure (6) of the research model and the output of Amos in Table (6), the impact was statistically significant as the (C. R) value was (12.784), being greater than (1.964), and the significance level (.000) was less than (0.05). Furthermore, the path coefficient was (0.75), suggesting that the impact was in a decisive direction and confirming that the heightened consideration paid towards Human Resources Management causes an increase in the organizational commitment. Thus, $(57 \%)$ of the organizational commitment is attributed or explained by Human Resources Management, which is considered as a major influence of the underlying variables since it is higher than $(25 \%)$.

(H3): There is significant positive correlation between organizational commitment and employee performance in Jumhouria bank.

Concerning this, the results of the third research hypothesis showed the presence of a decisive and direct effect of the organizational commitment on the employee performance. This is evidenced as seen in the research model displayed in Figure (6) and Table (6). The impact stated in this research hypothesis was statistically significant because the (C. R) value was (9.794), which was greater than (1.964), and the significance level $(0.000)$ is less than $(0.05)$. Moreover, the path coefficient was $(0.67)$, which indicates that there is a positive direction, highlighting the evidence that the increased attention to the organizational commitment to the development of employee performance. The results also show that the overall impact on the of employee performance. Was estimated (0.92), which means that (92\%) of the employee performance. Was due to both Human Resources Management and the organizational commitment. 
(H4): There is significant positive correlation between Human Resources Management and employee performance through organizational commitment in Jumhouria bank.

The study's hypothesis confirmed the positive and indirect effect of Human Resources Management on the employee performance. In other words, there is an effect of Human Resources Management on the employee performance through the mediating factor, organizational commitment. According to the outcome in table (7), the value of this indirect impact $(0.50)$ was the resultant rate of multiplying the path coefficient of the relationship among Human Resources Management and the organizational commitment (0.75) and the path coefficient of the relationship between organizational commitment and the employee performance (0.67). The overall impact was (0.85), which a result of adding the direct and indirect impact between Human Resources Management and the employee performance $(0.50+0.35=0.85)$.

Table 7. Results of the levels of Effect between the factors of the model

\begin{tabular}{|c|c|c|c|c|c|c|c|}
\hline \multirow{3}{*}{ Independent } & \multirow{3}{*}{ Mediation } & \multirow{3}{*}{ Dependent } & \multirow{3}{*}{$\begin{array}{r}\text { Indirec } \\
\text { Effect }\end{array}$} & \multirow{3}{*}{$\begin{array}{l}\text { Total } \\
\text { Effect }\end{array}$} & \multirow{2}{*}{\multicolumn{3}{|c|}{$\begin{array}{c}\text { Indirec Effect Test } \\
\text { Result Sobel Test }\end{array}$}} \\
\hline & & & & & & & \\
\hline & & & & & S.T.S & O.T.P & T.T.P \\
\hline HRM & $\begin{array}{c}\text { organizational } \\
\text { commitment }\end{array}$ & $\begin{array}{l}\text { Employee } \\
\text { performance }\end{array}$ & 0.50 & 0.85 & 8.814 & .000 & .000 \\
\hline
\end{tabular}

\section{Conclusion and Discussion of Results}

The primary purpose of this research was to examine the impact of human resource practices on Employee Performance and organizational commitment in banking sector in Libya. The study has concluded with many results, and one of the most important results is that, there is a positive relationship between the human resource management policies and the employees' performance. The obtained value of direction is 0.35 with positive direction, and this high percentage of employees' performance obtained due to the policy factor, these results agree with Morris \& Snell (2010), G. Demo, E. R. Neiva, I. Nunes, and K. Rozzett, (2012), Boselie, Dietz, \& Boon, (2005); Menezes, Wood, \& Geladi, (2010); Subramony, (2009), Guest and Conway (2011) \& Beauvallet and Houy (2010). Also, the value of the direction between the policy factor and the organizational commitment is 0.75 and it is also with a positive direction. Besides, the value of the direct impact between them is 0.57. In addition, the value of the direction between organization commitment factor and the employees' performance is 0.67 and in a positive direction, these results agree with Legge, (2006), Decotiis \& Summers, (1987); Mathieu \& Zajac, (1990). Delaney and Huselid (1996). While, the percentage of the total impact is $92 \%$ on the employees' performance, and this is due to the human resource management policies and the organization commitment as well. The study also found that there is an indirect positive effect to the human resource management policies through the organizational commitment with a percentage higher than the direct impact, whereas the value of the indirect impact 0.50. This result confirmed with Yazam and Ahmid (2012). At the end the researcher recommends that all policy makers of human resource management should pay more concern on policies and practices related to the employees which results into developing the employees' performance, also policy makers inside the bank should concentrate on emotional aspects of the employees which in turn result into a higher positive influence on their performance compared with the direct impact on their performances.

\section{Limitations and Future Studies}

Although this study provides several theoretical and practical implications, there are several limitations that would provide excellent opportunities for future contributions to this important stream of research. First, since the study focus was the Banking Industry in Libya, the generalization of the results to other countries is limited. Future studies may test the relationship between Human Resources Management and employee performance in other countries in the same region. Second, cross-sectional design of the research could be another limitation. Additional research using a longitudinal methodology addresses the relationship between Human Resources Management and employee performance through another mediator variable.

\section{References}

Abdul Hameed, M. H. M. (2014). Impact of Compensation on Employee Performance (Empirical Evidence from Banking Sector of Pakistan). International Journal of Business and Social Science, 5(2), 302-309.

ALDamoe, F. M. A., Yazam, M., \& Ahmid, K. B. (2012). The mediating effect of HRM outcomes (employee 
retention) on the relationship between HRM practices and organizational performance. International Journal of Human Resource Studies, 2(1), 75-88. http://dx.doi.org/10.5296/ijhrs.v2i1.1252

Armstrong, M. (2009). Armstrong's handbook of human resource management practice (11th ed.). London: Kogan Page.

Barney, J. (1991). Firm resources and sustained competitive advantage. Journal of Management, 17(1), 99-120. http://dx.doi.org/10.1177/014920639101700108

Beauvallet, G., \& Houy, T. (2010). Research on HRM and lean management: a literature survey. International Journal of Human Resources Development and Management, 10(1), 14-33. http://dx.doi.org/10.1504/IJHRDM.2010.029444

Beck, K., \& Wilson, C. (2001). Have we studied, should we study, and can we study the development of the development of commitment? Methodological issues and the developmental study of work-related commitment.

Bohlander, G. W., \& Snell, S. (2009). Administração de recursos humanos (14th ed.). São Paulo: Cengage.

Boselie, P., Dietz, G., \& Boon, C. (2005). Comunalities and contradictions in HRM and performance research. Human Resource Management Journal, 15(3), 67-94. http://dx.doi.org/10.1111/j.17488583.2005.tb00154.x

Boxall, P., \& Purcell, J. (2000). Strategic human resource management: where have we come from e where should we be going? International Journal of Management Reviews, 2(2) 183-203. http://dx.doi.org/10.1111/1468-2370.00037

Browne, M. W., \& Cudeck, R. (1993). Alternative ways of assessing model fit. Sage. Focus Editions, 154, 136.

Chênevert, D., \& Tremblay, M. (2009). Fits in strategic human resource management and methodological challenge: Empirical evidence of influence of empowerment and compensation practices on human resource performance in Canadian firms. The International Journal of Human Resource Management, 20(4), 738-770. http://dx.doi.org/10.1080/09585190902770547

Christen, M., Iyer, G., \& Soberman, D. (2006). Job satisfaction, job performance, and effort: A reexamination using agency theory. Journal of Marketing, 70(1), 137-150.

Cohrs, J. C., Abele, A. E., \& Dette, D. E. (2006). Integrating situational and dispositional determinants of job satisfaction: Findings from three samples of professionals. The Journal of Psychology, 140(4), 363-395.

Combs, J., Liu Y., Hall, A., \& Ketchen, D. (2006). How much do high-performance work practices matter? A meta-analysis of their effects on organizational performance. Personnel Psychology, 59(3), 501-528. http://dx.doi.org/10.1111/j.1744-6570.2006.00045.x

Davision, W. N. III, W. N., Worrell, D. L., \& Fox, J. B. (1996). Early retirement programs and firm performance.

DeCotiis, T., \& Summers, T. (1987). A path analysis of a model of the antecedents and consequences of Organizational Commitment.

Delaney, J., \& Huselid, M. (1996). The impact of human resource management practices on perceptions of organizational performance.

Demo, G., Neiva, E. R., Nunes, I., \& Rozzett, K. (2012). Human Resources Management Policies and Practices Scale (HRMPPS): Exploratory and Confirmatory Factor Analysis. Brasilia Administration Review. Retrieved from http://www.anpad.org.br/bar

Frenkel, S., Restubog, S. L. D., \& Bednall, T. (2012). How employee perceptions of HR policy and practice influence discretionary work effort and co-worker assistance: evidence from two organizations. The International Journal of Human Resource Management, 23(20), 4193-4210. http://dx.doi.org/10.1080/09585192.2012.667433

Gaafar, M. A. (2012). The Impact of Human Resource management Practices on Organizational Performance in Saudi Banking Sector. European Journal of Business and Management, 4(21), 188-197.

Guest, D. (1987). Human resource management and industrial relations. The Journal of Management Studies, 24(5), 503-521. http://dx.doi.org/10.1111/j.1467-6486.1987.tb00460.x

Guest, D. (1998). Is the psychological contract worth taking seriously? Journal of Organisational Behaviour, 19(S1).

Guest, D., \& Conway, N. (2011). The impact of HR practices, HR effectiveness and a 'strong HR system' on 
organisational outcomes: a stakeholder perspective. The International Journal of Human Resource Management, 22(8), 1686-1702. http://dx.doi.org/10.1080/09585192.2011.565657

Hafeez, U. (2015). Impact of Training on Employees Performance (Evidence from Pharmaceutical Companies in Karachi, Pakistan). Business Management and Strategy, 6(1), 49-64.

Hair, J., Black, B., Babin, B., Anderson, R., \& Tatham, R. (2006). Multivariate Data Analysis (6th ed.). Upper Saddle River, NJ: Prentice-Hall.

Huselid, M. A. (1995). The impact of human resource management practices on turnover, productivity, and corporate financial performance. Academy of Management Journal, 38(3), 635-672.

Ichnionwski, C., Shaw, K., \& Prennush, G. (1995). The Effect of Human Resource Practices on productivity. NBER.

Katz, J., Aldrich, H., Welboune, T. M., \& Williams, P. (2000). Guest edititor's comments: Especial issue on human.

Lawler, E. E. III, \& Porter, L. W. (1967). The Effect of Performance on Job Satisfaction. Industrial Relations, $20-28$.

Legge, K. (2006). Human resource management. In S. Ackroyd, R. Batt, P. Thompson, \& P. S. Tolbert (Eds.), The Oxford handbook of work and organization (pp. 220-241). New York: Oxford University Press.

Lim W. M. (2012). Organisational strategic human resource management - The case of lehman brothers. Journal of Management Research, 4(2), 1-8. http://dx.doi.org/10.5296/jmr.v4i2.1368

MacCallum, R. C., Browne, M. W., \& Sugawara, H. M. (1996). Power Analysis and Determination of Sample Size for Covariance Structure Modeling. Psychological Methods, 1(2), 130-149.

Marsh, H. W., \& Hocevar, D. (1985). Application of confirmatory factor analysis to the study of self-concept: First-and higher order factor models and their invariance across groups. Psychological bulletin, 97(3), 562-582. http://dx.doi.org/10.1037/0033-2909.97.3.562

Mathieu, J. E., \& Zajac, D. M. (1990). A review and meta-analysis of the antecedents, correlates, and consequences of organizational commitment.

McCloy, R. A., Campbell, J. P., \& Cudeck, R. (1994). A confirmatory test of a model of performance determinants. Journal of Applied Psychology, 79(4), 493-505.

McDonald, R. P., \& Marsh, H. W. (1990). Choosing a multivariate model: No centrality and goodness of fit. Psychological Bulletin, 107(2), 247-255.

Menezes, L. M., Wood, S., \& Gelade, G. (2010). The integration of human resource and operation management practices and its link with performance: a longitudinal latent class study. Journal of Operations Management, 28(6), 455-471. http://dx.doi.org/10.1016/j.jom.2010.01.002

Meyer, J. P., \& Allen, N. J. (1997). Commitment in the workplace: Theory, research, and application. SAGE Publications, Inc.

Morris, S., \& Snell, S. (2010). The evolution of HR strategy: adaptations to increasing global complexity. In A. Wilkinson, N. Bacon, T. Redman, \& S. Snell (Eds.), The SAGE handbook of human resource management (pp. 84-99). London: Sage.

Oladipo, J. A., \& Abdalkader, D. S. (2011). Strategic Human Resource Management and Organizational organizational commitment. Human Relations, 40(7), 445-70.

Pfeffer, J. (1994). Competitive Advantage Through people. Harvard Business School Press, Boston.

Pfeffer, J. (2005). Producing sustainable competitive advantage through effective management of people. Academy of Management Executive, 19(4), 95-108.

Porter, L. W., \& Lawler, E. E. (1968). Managerial attitudes and performance. Homewood, Ill.: R.D. Irwin.

Porter, M. (1990). The Competitive Advantage of Nations. The Free Press, A Division of McMillan, Inc., New York.

Qaisar, M., Safdar, R., \& Sufyan, M. (2012). Exploring Effect of Organizational Commitment on Employees' Performance. Interdisciplinary Journal of Contemporary research in Business, 3(11), 248-255.

Rayton, B. A. (2006). Examining the interconnection of job satisfaction and organizational commitment: An application of the bivariate probit model. The International Journal of Human Resource Management, 17(1), 
139-154.

Rebecca, A., Stephen, G., Mahima, S., Howard, M., \& Shelley, M. (2013). The Influence of Organizational Commitment and Individual Competence on Performance: In the Learning Organization Perspective. International Journal of Business and Behavioral Sciences, 3(8), 20-36.

Rubino, T., Demo, G., \& Traldi, M. T. F. (2011, April). As políticas de gestão de pessoas influenciam o bem-estar no trabalho? Proceedings of the Congresso Iberoamericano de Psicologia das Organizações edo Trabalho, Florianópolis, SC, Brazil, 2.

Salleh, M., Aziz, A., Shaladin, M., \& Muhammad, A. (2013). Fairness of Performance Appraisal and Organizational Commitment. Asian Social Science, 9(2), 122-128. http://dx.doi.org/10.5539/ass.v9n2p121

Sarbariya, R., \& Khita, A. R. (2011). Human Resource Practices and Its Effect on Employee Job Satisfaction: A study on selected small and medium sized iron \& steel firm in India public policy and administration research.

Scarpello, V., Ledvinka, J., \& Bergmann, T. (1995). Human resource management: Environments and functions (2nd ed.). Cincinnati, OH: Southwestern College Publishing.

Schneider, B., \& Bowen, D. (1985). Employee and customer perceptions of service in banks: replication and extension. Journal of Applied Psychology, 70(3), 423-433. http://dx.doi.org/10.1037/0021-9010.70.3.423

Seonghee, C., Woods, R. H., Soocheong, J., \& Dem, M. E. (2006). Measure the Impact of human resource management practices on hospitality firms performance. Hospitality Management, 25, 262-277.

Serpell, A., \& Ferrada, X. (2007). A competency-based model for construction supervisors in developing countries. Personnel Review, 36(4), 585-602. http://dx.doi.org/10.1108/00483480710752812

Singar, E. J., \& Ramdsen, J. (1972). Human resources: Obtaining results from people at work. UK: McGraw-Hill.

Stone, D. L., Stone-Romero, E. F., \& Lukaszewski, K. (2007). The impact of cultural values on acceptance and effectiveness of human resource management policies and practices. Human Resource Management Review, 17(2), 152-165. http://dx.doi.org/10.1016/j.hrmr.2007.04.003

Storey, J. (1995). New perspectives in human resource management. London: Routledge.

Subramony, M. (2009). A meta-analytic investigation of the relationship between HRM bundles and firm performance. Human Resource Management, 48(5), 745-768. http://dx.doi.org/10.1002/hrm.20315

Tanveer, Y., \& Zeeshan, M. (2011). The way Human Resource Management (HRM) Practices Effect Employees Performance: A Case of Textile Sector. International Journal of Economics and Management Sciences, 1(4), 112-117.

Ulrich, D., Halbrook, R., Meder, D., Stuchlik, M., \& Thorpe, S. (1991). Employee and customer attachment: synergies for competitive. Human Resource Planning, 14(2), 89-102.

Uysal, G. (2012). For the development of effective HRM systems: inter-relationships between HRM practices using correlation analysis. World Review of Entrepreneurship. Management and Sustainable Development, 8(1), 1-12. http://dx.doi.org/10.1504/WREMSD.2012.044483

Vakola, M., Soderquist, K. E., \& Pratascos, G. P. (2007). Competence management in support of organizational $\begin{array}{lllll}\text { change. International Journal of 260-275. } & \text { Manpower, }\end{array}$ http://dx.doi.org/10.1108/01437720710755245

Wilkinson, A. (1990). Business Strategy and the management of Labour (University of Durham PhD. working paper 5333). Columbia University.

Yeh, H., \& Shih, Ch. (2012). The Mediating Effect of Organizational Commitment on Leadership Type and Job Performance. The Journal of Human Resource and Adult Learning, 8(2), 50-59.

$\mathrm{Yu}$, B. B., \& Egric, C. P. (2005). Human resource Management Practices and affective organizational commitment: A comparison of Chinese employees in a state-owned enterprise and a joint venture.

Zhang, Z. (1999). Developing an instrument for measuring TQM implementation in a Chinese context. SOM Research Report, 99A48, University of Groningen, Groningen. 
Appendix A

\begin{tabular}{|c|c|c|}
\hline $\begin{array}{l}\text { Measures used for } \\
\text { (HRM) dimension }\end{array}$ & Items & Description \\
\hline \multirow{5}{*}{$\begin{array}{l}\text { Recruitment and } \\
\text { Selection }\end{array}$} & RS2 & $\begin{array}{l}\text { The organization I work for widely disseminates information about both } \\
\text { external and internal recruitment processes }\end{array}$ \\
\hline & RS1 & $\begin{array}{l}\text { The organization I work for discloses information to applicants regarding the } \\
\text { steps and criteria of the selection process. }\end{array}$ \\
\hline & RS4 & $\begin{array}{l}\text { The organization I work for communicates performance results to candidates at } \\
\text { the end of the selection process. }\end{array}$ \\
\hline & RS5 & $\begin{array}{l}\text { Selection tests of the organization where I work are conducted by trained and } \\
\text { impartial people. }\end{array}$ \\
\hline & RS7 & $\begin{array}{l}\text { The organization I work for has competitive selection processes that attract } \\
\text { competent people. }\end{array}$ \\
\hline \multirow{4}{*}{ Involvement } & I6 & The organization I work for treats me with respect and attention \\
\hline & $\mathrm{I} 2$ & $\begin{array}{l}\text { In the organization where I work, there is an environment of understanding and } \\
\text { confidence between managers and employees. }\end{array}$ \\
\hline & $\mathrm{I} 3$ & $\begin{array}{l}\text { The organization I work for favors autonomy in doing tasks and making } \\
\text { decisions. }\end{array}$ \\
\hline & I5 & $\begin{array}{l}\text { The organization I work for encourages my participation in decision- making } \\
\text { and problem- solving. }\end{array}$ \\
\hline \multirow{4}{*}{$\begin{array}{l}\text { Performance } \\
\text { Appraisal }\end{array}$} & PA6 & $\begin{array}{l}\text { The organization I work for discusses competency-based performance appraisal } \\
\text { criteria and results with its employees. }\end{array}$ \\
\hline & PA1 & $\begin{array}{l}\text { In the organization where I work, competency-based performance appraisal } \\
\text { provides the basis for an employee development plan. }\end{array}$ \\
\hline & PA3 & $\begin{array}{l}\text { In the organization where I work, competency-based performance appraisal is } \\
\text { the basis for decisions about promotions and salary increases. }\end{array}$ \\
\hline & PA5 & $\begin{array}{l}\text { The organization I work for periodically conducts competency-based } \\
\text { performance appraisals. }\end{array}$ \\
\hline \multirow{4}{*}{$\begin{array}{l}\text { Compensation } \\
\text { and Rewards }\end{array}$} & CR7 & $\begin{array}{l}\text { In the organization where I work, I get incentives such as promotions, } \\
\text { commissioned functions, awards, bonuses, etc. }\end{array}$ \\
\hline & CR1 & $\begin{array}{l}\text { The organization I work for offers me a salary that is compatible with my skills, } \\
\text { training, and education. }\end{array}$ \\
\hline & CR3 & $\begin{array}{l}\text { The organization I work for remunerates me according to the remuneration } \\
\text { offered at either the public or private marketplace levels. }\end{array}$ \\
\hline & CR4 & $\begin{array}{l}\text { The organization I work for considers the expectations and suggestions of its } \\
\text { employees when designing a system of employee rewards. }\end{array}$ \\
\hline \multirow{3}{*}{$\begin{array}{l}\text { Training and } \\
\text { Development }\end{array}$} & TD4 & In the organization where I work, training is evaluated by participants. \\
\hline & TD3 & The organization I work for stimulates learning and application of knowledge. \\
\hline & 5 & In the organization where I work, training needs are identified periodically. \\
\hline $\begin{array}{l}\text { Measures used for } \\
\text { employee } \\
\text { performance } \\
\text { dimension }\end{array}$ & Items & Description \\
\hline \multirow{4}{*}{$\begin{array}{l}\text { Efficiency of the } \\
\text { Work }\end{array}$} & EW2 & I feel dedication, seriousness and ability to take responsibility. \\
\hline & EW1 & $\begin{array}{l}\text { I enjoy professional skill or professionalism and technical knowledge required } \\
\text { to carry out the work efficiently. }\end{array}$ \\
\hline & EW3 & I do my work according to specific policies and procedures. \\
\hline & EW6 & I feel satisfied with the work I do in the bank. \\
\hline $\begin{array}{l}\text { Planning the } \\
\text { Work }\end{array}$ & PW4 & $\begin{array}{l}\text { lanning the work before starting its implementation contributes } t \\
\text { ooals that need to be achieved. }\end{array}$ \\
\hline
\end{tabular}


PW 1 I have the ability to plan my work and its accomplishment according to the planned schedule.

PW 3 Planning the work before starting its implementation gives me a sense of comfort.

PW 6 Planning the work before starting its implementation increases my ability to focus on the completion of the work assigned automatically.

CI7 I am careful or keen to make changes in the working methods of each period.

CI2 I stay away from repeating what others do in solving work-related problems.

$\begin{array}{lll}\begin{array}{c}\text { Creativity and } \\ \text { Innovation }\end{array} & \text { CI3 } & \begin{array}{l}\text { I feel bored of repeating the same procedures in doing the work. } \\ \text { I have the ability to put forward ideas and solutions rapidly to face work-related } \\ \text { problems. }\end{array} \\ \text { CI4 } & \text { I have the ability to express my thoughts fluently and freely. } \\ \text { ME6 } & \begin{array}{l}\text { Feeling proud of the work represents a motivation for me to make extra efforts. } \\ \text { I have the desire and willingness to work outside official working hours for fast } \\ \text { delivery. }\end{array}\end{array}$

Making Efforts ME4 The bank is keen on providing additional benefits to employees to motivate ME4 them to make more efforts.

ME7 The administration provides those employees who do their work tasks well with an increase in the wages or salaries.

\begin{tabular}{|c|c|c|}
\hline $\begin{array}{l}\text { Measures used for } \\
\text { organizational } \\
\text { commitment } \\
\text { dimension }\end{array}$ & Items & Description \\
\hline \multirow{5}{*}{$\begin{array}{l}\text { Affective } \\
\text { Commitment }\end{array}$} & `AC3 & I feel the desire to make a major effort to achieve the objectives of the bank. \\
\hline & AC 1 & There is an emotional attachment to the bank where I work. \\
\hline & $\mathrm{AC} 4$ & I do not want to work in other banks. \\
\hline & $\mathrm{AC} 6$ & I feel as if I was working in a family atmosphere at the bank where I work. \\
\hline & $\mathrm{AC} 8$ & I quite consider that the bank's problems as my own specific problems. \\
\hline \multirow{4}{*}{$\begin{array}{l}\text { Continuous } \\
\text { Commitment }\end{array}$} & $\mathrm{CC} 3$ & I strongly care about the future of the bank where I work. \\
\hline & $\mathrm{CC} 1$ & $\begin{array}{l}\text { I want to remain/ stay in the bank no matter what other alternative opportunities } \\
\text { are available to me }\end{array}$ \\
\hline & $\mathrm{CC} 4$ & Leaving my work in this bank causes problems in my life. \\
\hline & $\mathrm{CC} 8$ & I belong to the place where I work and I have no desire to leave it. \\
\hline \multirow{4}{*}{$\begin{array}{l}\text { Normative } \\
\text { Commitment }\end{array}$} & NC8 & Continued loyalty is a moral value. \\
\hline & $\mathrm{NC} 3$ & I consider moving from one bank to another immoral. \\
\hline & $\mathrm{NC} 4$ & I consider my commitment to the bank a moral obligation. \\
\hline & NC 5 & I would feel guilty if I left work in the bank. \\
\hline
\end{tabular}

\section{Copyrights}

Copyright for this article is retained by the author(s), with first publication rights granted to the journal.

This is an open-access article distributed under the terms and conditions of the Creative Commons Attribution license (http://creativecommons.org/licenses/by/4.0/) 